\title{
Juvenile Delinquency as Manifested by Drug Abuse in Gweru Secondary Schools in Zimbabwe
}

\author{
Philip Gazimbe, Tungu Mufunani Khosa \\ Faculty of Education: Zimbabwe Open University
}

*Corresponding Author: Philip Gazimbe, Faculty of Education: Zimbabwe Open University

\begin{abstract}
This study investigated magnitude of juvenile delinquency as manifested by the prevalence of drug abuse in secondary schools in Gweru District in order to come up with practical suggestions to combat the practice. The study employed the quantitative methodology and used the descriptive design. The population comprised of all the 60 secondary schools in the district and the sample was made up of pupils from 4 of the secondary schools, which were randomly selected. From each school 50 pupils were randomly selected to arrive at a sample of 200 respondents. Data were collected by means of a questionnaire. The study revealed that drug abuse in most schools existed and that there was little evidence to show that schools were coming up with strategies to combat it. School authorities and other community stakeholders should treat drug abuse in schools as a major challenge that requires collective effort to address. The study also recommends that the school curriculum should include content and concepts addressing drug abuse as one of the core courses.
\end{abstract}

Keywords: Juvenile, manifestation, delinquency, drug abuse, combating, secondary schools, district

\section{INTRODUCTION}

Juvenile delinquency as a concept is associated with ideas such as deviance, indiscipline, bullying, violence, promiscuity and drug use by young people between the ages of about thirteen to eighteen years (Jeram, 2010). The underlying drivers of such anti-social conduct which causes the young people to depart from what society values and holds in esteem forms the bedrock of juvenile delinquency. Deviance suggests moving away from what a given society regards as the norm, deviant behaviour results in breaking of established beliefs, practices and laws that are established by a given society (Jeram, 2010). Indiscipline in this context entails acting in a manner that violates agreed social norms and values, systems and regulations. In a school set up, it relates to violation of school rules and procedures. Drugs are substances, in this context, which when consumed have the effect of influencing the person to act irrationally or in an affected way. In Zimbabwe the issue of drug abuse in schools can be historically linked to the period immediately soon after independence (Chikoko, 2013). The policy of education for all opened the school gates even for those young adults who had spent time using drugs during the liberation struggle as a survival strategy. Since then the practice has remained a challenge in both primary and secondary schools. As Mpofu (2011) argues, students who often engage in numerous anti-social behaviours such as fighting, bullying, theft and vandalism of school property are most likely to be under the influence of drugs. Drug abuse may prevent the young adults from exploiting unique opportunities offered during their adolescent days such as the chance to acquire decent education (Nderezina, 2008). The use of drugs by pupils has a ripple effect on the management and learning process of pupils and on the general peace and stability of any society. It is, therefore, on account of this information that this study set out to investigate the magnitude of the problem of drug abuse in the schools in order to come up with strategies to combat the menace not in the schools but in society as a whole.

\section{LITERATURE REVIEW}

Drug and substance abuse as a manifestation of juvenile delinquency have become serious problems across the world. According to Gilman et.al (2005), drug abuse is the use of drugs in ways that are not approved of by one's culture; and some possible consequences of drug abuse are intoxication, impaired cognition and lack of self-control. There are a number of reasons that cause drug abuse by 
secondary school learners. Research found the following as the most common reasons (Brown, 2004; Lembersky, 2004 and Health, 2004).

- The learner strives to be accepted by the peer group and wants to fit in and be part of the peer group and it is important for the learner to conform to the peer group.

- Unhealthy marital relationship and weak maternal and paternal figures can predispose the learner to drug abuse. The absent maternal or paternal figure who does not fulfill his or her role of authority adequately or who provides the learner with inadequate social support in handling stressful life events or societal pressures often cause identification problems and a negative selfesteem in the learner.

- Drugs serve as an escape mechanism for coping with stress, school and personal problems. The learner who cannot handle everyday school, sports, family or emotional problems is more likely to abuse drugs, as drugs represent a coping and escape mechanism.

- The learner with a negative self image may feel inferior and he/she may need recognition. He/she may want to feel in control. In this case the learner chooses to abuse drugs since he/she experiences a temporary feeling of independence and power whilst under the influence of drugs.

It is therefore important for parents, learners, educators and adults to identify the physical and psychological signs and symptoms of drug abuse. The earlier the identification, the greater the success of the intervention programme (Jeram, 2010). Researchers are agreed that secondary school learners who abuse drugs may show the following symptoms.:

- The learner experience deterioration in scholastic performance. The learner achieves low grades and may display hostile, defiant and unco-operative behavior towards others in the school. The learner may also experience a drop in motivation, concentration, general achievement, interest in sport and extra-mural activities. Under these circumstances, school is of no interest to the learner and truancy often results (Much, 2002; Jeram, 2010; Rutherford, 2001 and Donald, Loliwana and Lazarus, 2002). In some instances, the learner may be involved in constant conflict situations and may experience a breakdown in communication and a general deterioration in interpersonal relationships (Jeram, 2010). On the other hand, Marsh (1992) argues that the learner may experience extremes of behaviour and may either become extremely aggressive or unusually docile. On the other hand, he/she may be defiant, unco-operative, moody, cranky or verbally abusive and on the other hand he/she may be jovial, pliable, sociable and agreeable.

According to Jeram (2010) smoking drugs such as dagga, cigarettes and opium causes various respiratory problems and diseases such as bronchitis, pneumonia, cancer of the mouth, throat, larynx, esophagus, bladder, pancreas and kidney. Furthermore, according to Lifescope (2004) smoking can aggravate asthma and prevent enough oxygen and nutrients from nourishing the skin, giving rise to bad skin and a disease called psoriasis. Learners that smoke dagga ingest tetrahydrocammbino (THC), a substance that affects overall growth and health and this substance is fast-soluble and attaches itself to fatty tissue like the brain, reproductive organs, liver, kidneys and spleen causing damage to them (Sanca, 2004).

White and Bariola (2012) state that frequent drug users skip school or arrive late to class. Regular marijuana user are twice as likely as their classmates to receive low grades and continued marijuana use can cause memory gaps and also lead to decreased physical endurance or in extreme cases, it causes brain damage and death. Experimenting with drugs, particularly at a young age, often leads to dependence and those dependent on drugs sometimes support their habits by stealing, selling drugs to other and sexually prostituting themselves (Schwarz, 2012).

Early intervention and prevention activities should characterize a school's drug abuse program. School administrators should determine the extent of the drug problem within their jurisdiction before initiating a new intervention program (Roach, 2005). This according to Jeram (2010) can be accomplished by an anonymous survey of students and consultation with local law enforcement officials and collaborative plans should be made with parents, school boards, treatment agencies, and concerned groups within the community to ensure successful program. 
Teachers exert a significant influence on students' attitudes knowledge and opinions. According to Schwarz (2012) they can complement a school's drug abuse programme by incorporating drug abuse prevention strategies into their subject at any grade level. In addition, teachers must inform students that they disapprove of drug abuse (Knight and Levy, 2007). Any teacher who believes a student is abusing drugs should take action and the teacher should express concern to the student and to the parents, citing observed behaviours. Students who have been abusing drugs should also be referred to professionals for help and intervention strategies must be supported by school principals who should provide opportunities for teachers to meet for discussions about drug use and how they can fight the problem (Oupont and Humphreys, 2011). Finally, as Schawarz (2012) postulates, principals should follow up with students and / or parents after school personnel have intervened.

Parents are another important stakeholder that need to support the eradication of drug abuse by school pupils. As Jeram (2010) states, parents are the immediate caretakers of the children and have to fight drug abuse for the sustenance of our future generations. Strong relationships exist between parents and their children and this should be exploited to curb drug abuse among secondary school children (Roach, 2005). It is also the duty of the community to put in place structures that combat the tendency of drug abuse by the youths both in and out of school. Jeram (2010) states that communities should find ways of dealing with peer pressure because if it is allowed to persist, it would be disastrous to the young generations. Research also indicates that parental is approval does deter adolescent drug abuse. As Einesman and Teras (2007) states parents should stay actively involved in their teenager's life and should get to know their friends and their parents. Parents should also set and enforce curfews, and encourage participation in school and after-school activities as well as take time to ask what their child is thinking, feeling and doing every week and listen to the answers without interrupting (Jeram, 2010).

\section{Statement of the Problem}

The use of drugs by Zimbabwean youths has become a very topic issue. Barely a week passes by without stories in the press and other media reporting cases of indiscipline caused by youths under the influence of drugs. There is considerable abuse of marijuana (mbanje), pain relievers, alcohol, cough mixtures (containing codeine) and slimming tablets, as well as solvents especially glue. Most of these youths are of school going age. It therefore became necessary to investigate the prevalence of drug abuse in the secondary schools.

\section{RESEARCh QUESTIONS}

This study was guided by the following sub-questions:

1. What is the extent of drug abuse in secondary schools in Hwange District of Zimbabwe?

2. Are school authorities aware of the prevalence of drug abuse in their schools?

3. What strategies can be employed to combat the use of drugs in secondary schools?

\section{SigNifiCANCE OF THE STUDY}

The importance of the study lies in the fact that school authorities would be enlightened through evidence about the magnitude of the prevalence of drug abuse in their schools in order that they take practical measures to curb it.

\section{LIMITATIONS OF THE STUDY}

Pupils, who are the respondents in this study may not reveal all the information about themselves and their school mates, as they may not be sure about their fate since drug abuse is punishable both at school and in law. The use of both at school and in law. The use of questionnaires which promote anonymity was expected to mitigate this limitation.

\section{DELIMITATION OF THE STUDY}

The study was confined to one district in Zimbabwe, which is Gweru District. The sample comprised of 200 pupils composed of 102 males and 98 females. Views used were those from secondary school pupils and those from teachers, heads of schools, parents, police, health officials and community leaders were not solicited for this study. 


\section{Methodology}

The study employed quantitative methodology. Quantitative research was chosen because of its ability to enable this study finding to be generalized to other districts in the country (Borland, 2011). The quantitative methodology was also found useful in this study because it enabled the researchers to investigate 200 pupils' perceptions on the prevalence of drugs in the schools. The study settles for the survey research design. The study used simple random sampling for the sample and purposive sampling for the sub-sample. Data were gathered by means of a questionnaire which was made up of both close-ended and open-ended questions. The questionnaire was chosen because as Borg and Gall (2009) observe, it has the ability to reach many respondents who are at widely dispersed addresses and preserves anonymity which encourages greater honesty. However, Borland (2011) argues that the questionnaire generally has a low response rate and is generally has a low response rate and is inflexible in that it does not allow ideas or comments to be explored in-depth and many questions may remain unanswered. The researchers sought permission from the Ministry of Primary and Secondary Education to carry out the in the schools. After permission was granted, schools that were selected were then visited and the researchers personally requested to distribute the questionnaires to the respondents. These were enclosed in envelopes. At each school all those who were sampled were put in one classroom and completed the questionnaires. The researchers then collected the questionnaires at the end of the exercise. This enables the researchers to collect all the 200 questionnaires from all the respondents. The questionnaire produced descriptive statistics around the variables under study and these were computed and recorded for interpretation.

\section{FINDINGS AND DISCUSSION}

The study sought to investigate the prevalence of drug abuse in secondary schools in Zimbabwe. This section is presented in two parts; namely presentations of data and discussion.

\section{Presentation of Data}

Table1. Profiles of respondents by sex $(N=200)$

\begin{tabular}{|l|c|c|}
\hline Sex & Frequency & Percentage \\
\hline Male & 102 & 51 \\
Female & 98 & 49 \\
\hline Totals & $\mathbf{2 0 0}$ & $\mathbf{1 0 0}$ \\
\hline
\end{tabular}

The sample was made up of $51 \%$ boys and $49 \%$ girls. The statistical significance of this information is that there were more males than females at Advanced level classes in the secondary schools studied.

Table2. Responses to the question: "Which are the most commonly used drugs at your school?" $(N=200)$

\begin{tabular}{|l|c|c|}
\hline Type of drug & Frequency & Percentage \\
\hline Alcohol & 20 & 10 \\
Cigarettes & 10 & 5 \\
Glue & 10 & 5 \\
Mbanje (marijuana) & 144 & 72 \\
Others & 16 & 8 \\
\hline Totals & $\mathbf{2 0 0}$ & $\mathbf{1 0 0}$ \\
\hline
\end{tabular}

Most pupils abuse mbanje (marijuana) than any other substance (75\%). Pupils are also abusing other addictive substances although at a lesser degree.

Table3. Responses to the question: "Who are most likely to abuse drugs between boys and girls? (N=200)

\begin{tabular}{|l|c|c|}
\hline Drug abuse by sex & Frequency & Percentage \\
\hline Male & 176 & 88 \\
Female & 24 & 12 \\
\hline Totals & $\mathbf{2 0 0}$ & $\mathbf{1 0 0}$ \\
\hline
\end{tabular}

The majority of the respondents indicated that boys were more likely to use drugs at schools than girls (boys: $88 \%$; girls: 12\%). 
Juvenile Delinquency as Manifested by Drug Abuse in Gweru Secondary Schools in Zimbabwe

Table4. Responses to the question: "Which situation causes students to use drugs?" $(N=200)$

\begin{tabular}{|l|c|c|}
\hline Situation & Frequency & Percentage \\
\hline Students staying with both parents & 108 & 54 \\
\hline Students with one parent & 20 & 10 \\
\hline Students without any parent & 72 & 36 \\
\hline Totals & $\mathbf{2 0 0}$ & $\mathbf{1 0 0}$ \\
\hline
\end{tabular}

Students with both parents were said to be mostly like to engage in drug abuse (54\%), followed by those without any of their parents (36\%). Those with one parent were said to be least likely to use drugs.

Table5. Responses to the question: "Do pupils who take drugs perform better than those who do not?" $(N=200)$

\begin{tabular}{|l|c|c|}
\hline Response Category & Frequency & Percentage \\
\hline Yes & 26 & 13 \\
No & 170 & 85 \\
Not sure & 4 & 2 \\
\hline Totals & $\mathbf{2 0 0}$ & $\mathbf{1 0 0}$ \\
\hline
\end{tabular}

Respondents indicated that drugs did not help students to perform better in academic work.

Table6. Responses to the question: "Where do you think those who use drugs get them from?" (N=200)

\begin{tabular}{|l|c|c|}
\hline Source of drugs & Frequency & Percentage \\
\hline Buy & 112 & 56 \\
Get from peers & 56 & 29 \\
Get from school leavers & 28 & 14 \\
Grow at home & 2 & 1 \\
\hline Totals & $\mathbf{2 0 0}$ & $\mathbf{1 0 0}$ \\
\hline
\end{tabular}

Most pupils who abuse drugs in schools buy them using cash (56\%). Some get drugs from peers $(29 \%)$ and the rest are given by school leavers (14\%). A few grow drugs at home (1\%).

Table7. Responses to the question: "Are teachers and the head aware that pupils use drugs in the school?" $(N=200)$

\begin{tabular}{|l|c|c|}
\hline Response Categories & Frequency & Percentage \\
\hline To a great extent & 0 & 0 \\
To a moderate extent & 62 & 31 \\
To a lesser extent & 24 & 12 \\
Not at all & 100 & 53 \\
\hline Totals & $\mathbf{2 0 0}$ & $\mathbf{1 0 0}$ \\
\hline
\end{tabular}

Most respondents believe that their teachers and heads seem not to be aware of the prevalence of drug abuse at their schools. A few thought that teachers and heads are aware of just a few cases.

Table8. Responses to the question: “Are there strategies used to curb drug abuse at your school? ” $(N=200)$

\begin{tabular}{|l|c|c|}
\hline Response Category & Frequency & Percentage \\
\hline Yes & 10 & 5 \\
No & 174 & 87 \\
Not sure & 16 & 8 \\
\hline Totals & $\mathbf{2 0 0}$ & $\mathbf{1 0 0}$ \\
\hline
\end{tabular}

The majority of respondents indicated that there were no strategies carried out at their schools to curb drug abuse.

The questionnaire had two-open questions which complemented and bolstered data from the closeended questions. The first question wanted to find out from the students the times during which drugs were used in the schools. The most common responses were recorded as follows:

- In the toilets during break time and lunch time $\quad$ - $\quad 95 \%$

- Behind the bushes during sports times $\quad$ - $91 \%$

- During practical lessons when the teacher is away $\quad$ - $\quad 82 \%$

- On the way from and to home $\quad$ - $\quad 79 \%$

- At the shops - $\quad 75 \%$ 
The second question sought to find out from the pupils what they thought were the behaviours associated with pupils who had taken drugs. These responses were recorded in order of popularity:

- They show no respect to prefects and teachers

$\begin{array}{ll}- & 96 \% \\ - & 92 \% \\ - & 87 \% \\ - & 85 \% \\ - & 82 \% \\ - & 79 \% \\ - & 75 \%\end{array}$

- They fight with other pupils

- They do not do written work

- They come late after break and lunch time

- They have red eyes

- They sleep in class

- They steal money from other pupils

$96 \%$

$92 \%$

$87 \%$

$85 \%$

$82 \%$

$79 \%$

\section{DISCUSSION}

The most abused drug by pupils in the secondary schools in Hwange District is marijuana (mbanje in the local language). Other substances that are abused include alcohol, glue and cigarettes. This information reveals that pupils admit the prevalence of drug abuse in their schools. This situation requires that school authorities need to curb it at all costs because drug abuse as Nderezina (2008) posits, may prevent the young adults from exploiting unique opportunities offered during their adolescent days such as the chance to acquire decent education. Boys are the more likely to use drugs during their school days as shown by this study. However, school administrators and parents should also be aware that some girls may also fall in the trap of using drugs.

Students with both parents surviving were the ones said to be using drugs in the secondary schools that those with one or no parents at all, whereas those with one parent were said to be the least likely to use drugs. The reasons for pupils with both parents' propensity to use drugs could be attributed to the fact that this group of students have the "cash" to buy the drugs. It therefore behooves parents to be wary of giving their children large sums of money as pocket money. As Einesman and Teras (2007) postulates, parents should stay actively involved in their teenagers' life and should get to know their friends and their parents. Jeram (2010) further argues that parents should also set and enforce curfews, and encourage participation in school and after-school activities as well as take time to ask what their child is thinking, feeling and doing every week and listen to answers without interrupting.

Students are aware that those who take drugs experience serious challenges when it comes to academic. Pupils are therefore convinced that drugs are not "wise weeds" as some people allege (Nderezina, 2008). This finding tallies with observations by Much 92002), Jeram (2010), Rutherford (2001) and Donald, Lolwana and Lazarus (2002) who posit that the learner who takes drugs may experience deterioration in scholastic performance, achieves low grades and may display hostile, defiant and unco-operative behavior towards others in the school.

Most students who abuse drugs in schools by them using case they bring from home. A big number get these from their peers, who have the money to buy them because they have the cash. School leavers also provide drugs to a sizeable number of pupil who take drugs. It is therefore important that parents are made aware of the dangers of dishing out money to their school going children. As Jeram (2010) posits, parents are another important stakeholder that need to support the eradication of drug abuse by school pupils, and they are the immediate caretakers of the children and have to fight drug abuse for the sustenance of our future generations.

Schools had no strategies to curb drug abuse. It was business as usual in most of the schools as if drug abuse was not prevalent in the schools. As Schwarz (2012) opines, teachers and heads can complement a school's drug abuse programme by incorporating drug abuse prevention strategies into their subject at any grade level and teachers must inform students that they disapprove of drug abuse. Students who have been abusing drugs should also be referred to professionals for help and intervention strategies must be supported by school principals who should provide opportunities for teachers to meet for discussions about drug use and how they can fight the problem.

Behaviours associated with pupils who take drugs include aggressiveness, failure to do assignments, coming late to school, sleeping in class and stealing money. Pupils are aware of the negative behaviours associated with drug abuse. As March (1992) states, a learner who takes drugs may either become extremely aggressive or unusually docile, on the other hand, he/she may be defiant, uncooperative, moody, cranky or verbally abusive and on the other hand he/she may be jovial, pliable, sociable and agreeable. 


\section{CONCLUSION}

Juvenile delinquency is a phenomenon that manifests itself in various forms. The abuse of drugs is one of them. The prevalence of drugs in secondary schools in Gweru District is a clear manifestation of the magnitude of juvenile delinquency in secondary schools. Pupils or students are using drugs like marijuana, beer, cigarettes and glue. Both boys and girls take drugs and teachers and parents should work together to curb the menace. Surprisingly, heads and teachers appear to be unaware of the magnitude of the existence of drugs in their schools or if they are aware, they seem not to be concerned about the problem. Students are aware of the negative behaviours associated with drug abuse and it is up to schools and other stakeholders to create proper structures for curbing the prevalence of drugs in the schools.

\section{RECOMMENDATIONS}

In light of the findings of this study, the researchers would like to make some recommendations:

- The secondary school curriculum should have a robust content and concepts addressing drug abuse among students and drug abuse lessons should be mandatory, well timetabled and properly supervised.

- There is need to increase teacher visibility in places like toilets and bushes around playgrounds to reduce student opportunities of abusing drugs.

- Pupils should not be allowed to go to the shops during school times without permission from the head.

- Parents should avoid giving their children huge amounts of pocket money as this money may be used for buying drugs.

- Schools should establish guidance and counseling centres to educate students on the dangers of drugs to their lives.

- The Zimbabwe Republic Police and the Ministry of Health and Childcare in conjunction with the Ministry of Primary and Secondary and Education should launch campaigns on dangers of dangers of drug abuse in order to curb the problem.

- Those students who cannot be assisted by school based disciplinary and counseling measures should be reported to the police (especially those who use banned substances) and be subjected to the laws of the country so that it serves as deterrent to other would-be offenders.

\section{REFERENCES}

Borg, E. \& Gall, R. (2009). Educational research and principles. New York: Longman.

Borland, R. (2011). Minimising the harm from nicotine use: Finding the right regulatory framework. Tobacco Control, 22(1): 6-9.

Brown, T. (2004). Understanding the psychological effects of stret drugs. Centurion: Universal Print Group.

Chikoko, V. (2013). Drug problems in schools. Harare: University of Zimbabwe.

Donald, D., Loliwana, P. and Lazarus, S. (2002). Educational psychology in social context. Pretoria: Oxford.

DuPront, R. \& Humpreys, K. (2011). A new paradigm for long-term recovery. Substance Abuse, 32(4): 1-6.

Einesman, F. \& Taras, H. (2007). Drug testing of students: A legal and public health perspective. Journal of Contemporary Health Law Policy, 23(7): 231-271.

Gilman, A. G., Godman, L. S. a\& Rall, T. W. (2009). The pharmacological basis of therapeutics. New York: MacMillan.

Heath, T. C. (2004). Alcohol anddrug abuse. New York: Longman.

Jeram, R. H. (2010). Substance abuse amongst secondary school learners. South Africa: University of Stellenbosch.

Knight, J. R. \& Levy, S. (2007). The national debate on drug testing in schools. Journal of Adolescents 41(12): 419-420.

Lembersky, R. B. (2004). Kids health: What to do if your kid is using drugs. Pretoria:Oxford.

Lifescope (2004). Children and drugs: part 2.http://lifespan.com/pages/how2s/drug child $2 \mathrm{html}$.

Marsh, D. D. (1992). Parental involvement in the school: To be or not to be. New York: Routledge. 
Mpofu, W. (2011). Community psychology. Harare: ZOU.

Much, C. (2002). Adolescent Drug abuse. London: MacMillan.

Nderezina, B. (2008). Understanding substance abuse in schools. Harare: College Press.

Roach, C. A. (2008). What are the odds? Random drug testing of students. A legal perspective Journal of School Nurse, 21(6): 176-179.

Rutherford, K. (2001). Kids health. Johannesburg: Lexicon.

Schwarz, A. (2012). Risky rise of the good grade pupil. New York: New York Times.

White, V. \& Bariola, E. (2012). Australian second school students use of tobacco, alcohol and over-the-counter and illicit substances in 2011. Victoria: Cancer Council.

Citation: Philip Gazimbe \& Tungu Mufunani Khosa. "Juvenile Delinquency as Manifested by Drug Abuse in Gweru Secondary Schools in Zimbabwe" International Journal of Humanities Social Sciences and Education (IJHSSE), vol 8, no. 7, 2021, pp. 119-126. doi: https://doi.org/10.20431/2349-0381.0807014.

Copyright: (C) 2021 Authors. This is an open-access article distributed under the terms of the Creative Commons Attribution License, which permits unrestricted use, distribution, and reproduction in any medium, provided the original author and source are credited. 